\title{
Property Taxation in North Macedonia
}

Stevan Gaber ${ }^{1}$, Ilija Gruevski²

${ }^{1}$ Goce Delcev University, Faculty of Economics, Krste Misirkov St., 10-A, Republic of Macedonia,e-mail: stevan.gaber@ugd.edu.mk

${ }^{2}$ Goce Delcev University, Faculty of Economics, Krste Misirkov St., 10-A, Republic of Macedonia, e-mail: ilija.gruevski@ugd.edu.mk

\begin{abstract}
Property taxes are one of the most essential taxes for the local authorities in any country. They are the main source for providing the municipality with finance in order to provide public goods and services. The last decade of unstable fiscal policy induced the necessity to readdress the role and the potential for reform or modernization of these sort of taxes. Considering the ever-growing thirst for larger expenses and going forward with fiscal decentralization process in North Macedonia, the local governments are confronted with the need to secure more finances. Therefore, the goal is to examine the current structure of property taxes in North Macedonia, compare them to some countries in Europe and finally to propose actions regarding some changes in local tax policy in order to improve the tax collection. Those changes should follow the growing inequalities among citizens in the country. In most developed countries the volume of property tax involves real estate and personal property, like vehicles, movable household items. Even some countries take into consideration the ownership of real estate in other countries around the world in order to really detect the wealth of some people. The last reaction from the central government in order to overcome the gap in local budgets (the government borrowed 50.000 .000 euros) was with intention to reduce the level of debt in most of the local municipalities and to secure their everyday functioning. Since then there are a lot of discussions in direction of better functioning of local governments through better collection of local revenues.
\end{abstract}

\section{Keywords}

Gift tax, inheritance tax, property tax, real estate tax, tax collection, tax reform.

\section{Introduction}

Before we address in specific way the real estate tax for the purpose of detailed and simplified analysis, we would not gone make distinction with the term property tax. Regardless their meaning, but in some federal countries, like USA, there is obvious difference among them. Real estate taxes are levied on real property such as homes, vacant houses, and property tax can include some personal property like automobiles and furniture. 
The registration of someone car can be considered as property tax. Those things are apparently well thought and designed in developed countries, but in transitional economies they are excluded from the authorities as tax receipts.

The collection of real estate tax is fundamental for the essential functioning of the local governments. Depending on the levied tax the communities will be able to provide qualitative public goods and services. Those revenues will be used for road maintenance, building new streets, securing communal services, snow assistance, traffic improvements, beautiful parks, educational investments, cultural amenities, sport activities, etc. Those communities that are well known for their quality of life will be able to attract more new citizens in pursue for better future.

Some of the essential aspect of real estate tax is the calculation. Real estates are assessed by licensed professionals with the intention to determine their fair market value. That value would be orientation point for future sale on open market. Therefore, if the property is assessed on 500.000 euros and the assessment rate is $80 \%$, then the assessed value for property tax will be 400.000 euros. When the local authorities apply the appropriate tax rate for property, for example of $1 \%$, then the annual real estate tax would be $1 \%$ from 400.000 euros or 4.000 euros.

The tax administration in USA rely on immovable objects in order to imply real estate tax, like barns, garages, houses, etc. However, they also tend to tax movable property like vehicles, livestock and furniture. Those objects that can be moved and not be damaged are considered as personal property, a segment of someone's wealth that in Macedonia is not treated for taxation with this tax. This categorization includes anything, but the real estate. That is why our country tends to start discussions for wealth taxes or reform of the current real estate taxes so they can obtain the wealthier people in the country that are not justifiably taxed. Some mobile homes are considered as debatable category. If they are parked on rented land, they are treated as personal property and must be licensed and taxed as cars. However, if it is parked on own land then they are taxed as real estate. Tax administration also gives certain exemptions for widows, disabled persons and families of military personnel.

Authorized tax assessor is obliged to visit the taxpayer once every five years in order to reassess the value of the real estate and adjust the tax. Tax can be assessed in three ways: evaluation of the sales, using the cost method and income estimation in case of renting the property. It is valuable for every taxpayer to see comparable estates in order to compare the sum of tax paid. The tax could be reduced only in the case of authorization of legal exemptions.

Real estate tax rates may be influenced by supranational authority and the changes they make. Changes in the tax rates can be result of:

- Decline in transfer of government revenues from grants. This could be serios trigger for adequate changes in the percentage of real estate tax in order to substitute the missing funds.

- High spending of local government. This reason is always opposite of the revenue deficit. It addresses the municipality's inability to restrict their costs for local goods and services. That kind of attitude always causes rise in property tax with intention to achieve balance.

- Exclusion of some property. This estate is exempted from standard taxation because they have been proven to have been valuable for the society. They can be farm residences, hospitals, churches and schools.

- Inability to fulfill tax obligation on real estate tax. This inability or disregard to tax obligation can result in higher interest rate on the amount of owed tax. This behavior can increase the real estate tax, but luckily it depends on taxpayer's awareness for more prosperous municipality. When taxes are paid on time this expense never appears. 


\section{Property Taxation in Other Countries.}

Property tax in Czech Republic is paid on the land and building facilities. Therefore, on the land, the tax is paid in relative to location (for building land) or value (agriculture land). The tax on building objects (houses, apartments) depends on size, type, usage, and it costs from 2 to 10 koruna on square meter. The basic tax liability is multiplied by coefficients (from 1 to 5 ), which are determined separately for every local government from their citizens. On the other side, the tax rate which is applied on agricultural land is $0,75 \%$ from the value of the land, but privileged rates apply for forests, lakes and fishing farms. For other kinds of land, the tax is determined according the location of the land and the tax is 2 korunas for square meter for building land, 5 korunas by square meter for industrial building land and 0,20 koruna in other cases. For the companies, the paid property tax represents deduction in calculation of corporate tax. The transfer tax on estate is $4 \%$ and is levied on higher amount of agreed price or reference price which is calculated by tax administration (according to similar transactions). If the referent price cannot be calculated, then the tax is paid on $75 \%$ from the value assessed by the licensed validator [1].

Since 2014, the estate and gift tax are abolished and incorporated in the personal income tax. The tax rate is $15 \%$ and the usual exemptions for heirs in first degree and persons that live together for one year are applied. The gifts in amount of 15.000 korunas are exempted from taxation. Previously, the estate and gift taxes were separate taxes, where the tax rates range from $0 \%$ to $20 \%$ (inheritance), i.e. from $0 \%$ to $40 \%$ (gift), depending from family relation [2]. Property tax in Slovenia is constituted from three major types of taxes: 1) direct income tax; 2) direct property taxes; and 3) indirect taxes. Tax administration is appointed by law to levy tax receipts, with exclusion of custom duties, excises and VAT on imported goods and services that are collected by Customs administration of Slovenia.

Regarding the direct property taxes, there are several main taxes: 1) inheritance and gift tax is applied on the transfer of real estate to descendant who pays for the tax or gift. The tax obligators are classified in four categories: first class that includes all direct successors and their spouses (exempted for tax obligation); second class targets parents, brothers and sisters and their heirs (tax rate is from $5 \%$ to $14 \%$ ); third class are grandfathers and grandmothers (tax rate from $8 \%$ to $17 \%$ ), and fourth class is including others (tax rate from $12 \%$ to $39 \%$ ). The progressive tax rates are applied according to value of real estate and tax base is market value (real estate is $80 \%$ from the market value). Besides the persons in first class of tax categorization, also the farmers are excluded when they inherit agricultural land and movable estate in value until 5.000 euros [3].

2) property tax is one that is applied on real estate in ownership and on the profit that arises from changes in land utilization (implemented in 2012 and applied on capital gains from buying land which utilization is transformed in building land after the purchase). In 2014 was introduced new property tax which will substitute previous four duties regarding this tax: usage fee for building land, property tax, fees for sustaining forest roads, and tax on property with higher value. Tax rates are as follows: $0,15 \%$ for residential buildings, 0,75 \% for commercial and industrial real estate, 0,50 \% for empty apartments / buildings (weekend houses) and building land for residential and non-residential buildings with value over 500000 euros the tax rate increases for $0,25 \%, 0,50 \%$ for unregistered residential real estates (for other illegal estate the tax rate multiplies by three). The tax base is determined by market value of the immovable estate according the property register. 3) boat tax is calculated on boats longer than 5 meters, which are taxed by rate that is declining for every year of usage of $5 \%$ relative to length and power of the boat, but the remaining tax obligation cannot be lower then $35 \%$ from the tax liability for new boat.

Property tax in UK from the table below ranks in place no. 1 in property tax collection as percentage of GDP. The recent changes in the taxation procedure are important for increasing number of oversea buyers. 1) Stamp duty land tax (SDLT) is payable on purchase of UK property. The tax rate would be according to the value and nature of the property, various rates depending on the value of the property. It is interesting that in UK there is additional tax 
on individual buyer (or spouse) when he / she possesses additional residence (anywhere in the world). The additional tax or surcharge is $3 \%$ SDLT, which brings the rates between 3 and $15 \%$. Also, there are some exemptions and deductions that are available.

Table 1 Stamp Duty Land Tax

\begin{tabular}{|l|c|c|}
\hline Value & Tax rate & Surcharge tax rate \\
\hline Up to $£ 125,000$ & $0 \%$ & $3 \%$ \\
\hline$£ 125,001-£ 250,000$ & $3 \%$ & $5 \%$ \\
\hline$£ 250,001-£ 925,000$ & $5 \%$ & $8 \%$ \\
\hline$£ 925,001-£ 1.5 m$ & $10 \%$ & $13 \%$ \\
\hline$£ 1,500,001+$ & $12 \%$ & $15 \%$ \\
\hline
\end{tabular}

Source: www.gov.uk

Inheritance tax (IHT) for not domiciled personal is payable on death and on gifts into trusts on UK assets. Residential properties hold by offshore companies are taxed since 2017 and are subject to inheritance tax on a shareholder's death. This tax is $40 \%$ above the Nil rate band (otherwise is $0 \%$ ), escorted with certain reliefs. If you give away your home to your children (including adopted, foster or stepchildren) or grandchildren your threshold can increase to $£ 500,000$. Your estate is worth $£ 500,000$ and your tax-free threshold is $£ 325,000$. The Inheritance Tax charged will be $40 \%$ of $£ 175,000$ ( $£ 500,000$ minus $£ 325,000$ ). Lot of the owners reduce the inheritance tax by giving their property to minor children. But this step can have tax disadvantages in some cases [4]. Non-Resident Capital Gains Tax (NRCGT) is payable on gains of non-resident disposals with UK residential property. The tax rate is $28 \%$ (in some case can be $18 \%$ ). This tax is paid on the increased value of the property, i.e. the change among buying price and the price of the value in the moment of disposal (without any deductions). Annual tax on enveloped dwellings (ATED) is an annual tax on properties worth over $£ 500,000$ and owned by 'non-natural persons', such as companies. ATED charges range between $£ 3,650$ and $£ 232,350$ per year depending on the property value; the charge increases annually in line with inflation.

After having a glimpse of real estate tax acts in few countries we can come to conclusion that the more developed countries are, the more detailed and capital oriented they are in controlling and taxing wealthier people. Just below we can see property tax participation as percentage of GDP. In order to see where Macedonia stands in this picture, I tried to calculate the data that were available for the last 2 years. The data for Macedonia were not available in the European Commission data.

As we can see from the table 2, several countries are leading the group in property tax collection, such as France, United Kingdom, Greece, Spain. Opposite of them, Estonia, Lithuania, Slovakia, Slovenia are at the bottom of the property tax receipts as percentage of GDP. There is apparent difference between the taxes as percentage from GDP in developed western countries, i.e. older member countries of EU against the, so called, new member countries from Central and Eastern Europe. According to my calculations, Macedonia is at the lower group of the table with result of 0,4 and 0,5 in 2019. Data before 2017 were not available, except in $2007-0,5$ [5]. Another thing that is obvious is that real estate tax is almost unchanged in last 10 years, with small tendency to increase. This could be good indicator why there are movements and debates everywhere towards changes in real estate tax [6]. 
Table 2 Taxes on property as \% of GDP - Total

\begin{tabular}{|c|c|c|c|c|c|c|c|}
\hline & 2013 & 2014 & 2015 & 2016 & 2017 & 2018 & $\begin{array}{c}\text { Ranking } \\
2018\end{array}$ \\
\hline EU-28 & 2.5 & 2.6 & 2.6 & 2.6 & 2.6 & 2.5 & \\
\hline EU-27 & 2.2 & 2.3 & 2.3 & 2.3 & 2.3 & 2.2 & \\
\hline EA-19 & 2.3 & 2.4 & 2.4 & 2.4 & 2.4 & 2.4 & \\
\hline Belgium & 3.6 & 3.6 & 3.6 & 3.6 & 3.5 & 3.5 & 3 \\
\hline Bulgaria & 0.9 & 0.9 & 0.9 & 0.9 & 0.8 & 0.8 & 21 \\
\hline Czechia & 0.6 & 0.6 & 0.6 & 0.6 & 0.6 & 0.6 & 25 \\
\hline Denmark & 2.6 & 2.6 & 2.7 & 2.5 & 2.5 & 2.5 & 6 \\
\hline Germany & 0.9 & 1.0 & 1.1 & 1.1 & 1.1 & 1.1 & 17 \\
\hline Estonia & 0.4 & 0.4 & 0.4 & 0.3 & 0.3 & 0.3 & 28 \\
\hline Ireland & 1.8 & 1.9 & 1.3 & 1.2 & 1.1 & 1.2 & 15 \\
\hline Greece & 3.6 & 3.2 & 3.5 & 3.5 & 3.4 & 3.2 & 4 \\
\hline Spain & 2.6 & 2.7 & 2.8 & 2.7 & 2.6 & 2.6 & 5 \\
\hline France & 4.3 & 4.5 & 4.6 & 4.7 & 4.8 & 4.6 & 1 \\
\hline Croatia & 1.2 & 1.1 & 1.2 & 1.1 & 1.1 & 1.2 & 14 \\
\hline Italy & 2.6 & 2.8 & 2.7 & 2.4 & 2.4 & 2.4 & 8 \\
\hline Cyprus & 1.3 & 1.3 & 1.5 & 1.1 & 1.1 & 0.9 & 20 \\
\hline Latvia & 1.1 & 1.2 & 1.2 & 1.2 & 1.1 & 1.0 & 19 \\
\hline Lithuania & 0.4 & 0.5 & 0.5 & 0.4 & 0.4 & 0.3 & 27 \\
\hline Luxembourg & 1.2 & 1.3 & 1.5 & 2.0 & 2.2 & 2.5 & 7 \\
\hline Hungary & 1.3 & 1.3 & 1.3 & 1.1 & 1.1 & 1.0 & 18 \\
\hline Malta & 0.9 & 0.9 & 1.0 & 1.1 & 1.1 & 1.3 & 13 \\
\hline Netherlands & 1.2 & 1.6 & 1.5 & 1.6 & 1.7 & 1.7 & 11 \\
\hline Austria & 0.8 & 0.8 & 0.9 & 0.8 & 0.8 & 0.8 & 22 \\
\hline Poland & 1.6 & 1.6 & 1.7 & 1.8 & 1.8 & 1.7 & 10 \\
\hline Portugal & 1.9 & 2.0 & 2.1 & 2.1 & 2.2 & 2.2 & 9 \\
\hline Romania & 0.9 & 0.9 & 0.9 & 0.8 & 0.7 & 0.6 & 23 \\
\hline Slovenia & 0.7 & 0.7 & 0.6 & 0.6 & 0.6 & 0.6 & 24 \\
\hline Slovakia & 0.4 & 0.4 & 0.4 & 0.4 & 0.4 & 0.4 & 26 \\
\hline Finland & 1.3 & 1.4 & 1.4 & 1.4 & 1.6 & 1.5 & 12 \\
\hline Sweden & 1.2 & 1.2 & 1.1 & 1.2 & 1.1 & 1.1 & 16 \\
\hline $\begin{array}{l}\text { United } \\
\text { Kingdom }\end{array}$ & 4.1 & 4.1 & 4.2 & 4.2 & 4.2 & 4.2 & 2 \\
\hline Iceland & 1.8 & 1.8 & 1.7 & 17.2 & 1.9 & 1.9 & \\
\hline Norway & 1.1 & 1.1 & 1.1 & 1.1 & 1.2 & 1.1 & \\
\hline $\begin{array}{l}\text { North } \\
\text { Macedonia* }\end{array}$ & $\mathrm{N} / \mathrm{A}$ & N/A & N/A & N/A & 0,46 & 0,48 & \\
\hline
\end{tabular}

Source: European Commission, DG Taxation and Customs Union, based on Eurostat data

Note: EU-27 represents EU Member States without UK

* The data is calculated from Reports for Local Governments [7].

\section{Property Tax Policy}

The property tax in North Macedonia determines the way of taxation on the following taxes:

- Real estate tax;

- Inheritance and gift tax;

- Transfer tax on real estate.

Real estate tax, according the law, is paid on immovable estate, except the estate that is primary exempt from taxation.

The tax subject is juridical and physical person owner of the real estate. When the proprietor of the proper estate is not known for the authorities, then taxpayer is the person, juridical and physical, that is using the real estate. Taxpayer for the real estate tax can be even the person 
who is using the estate, and if the estate is jointly owned by more persons, then every one of them will be liable upon their owners cut.

The tax rates are proportional and they range from 0,10 to $0,20 \%$. They can be set regarding the type of real estate. In this case the agricultural land that is not used for its purpose can be taxed with this law from three to five times more in comparison with the reference rates. The rates are determined with decision by the Council of the Community [8].

The tax base of the property tax is the market value of the immovable real estate. The calculation of the market value of the immovable real estate is made by person for assessment, a person employed in the local authority and upon local government request can be performed by licensed assessor. The market value is determined by appropriate methodology for assessment of market value of immovable estate. The taxpayer that lives in the building or apartment liable for real estate tax has the right for reduction on the calculated tax in amount of $50 \%$.

Inheritance and gift tax are paid upon the fixed real estate and the right for consumption and usage of real estate, which the inheritances i.e. gift receivers inherit or receive according the Law for inheritance or gift agreement. Also, it is paid for cash, money demand, securities and other forms of movable asset, only if the market value of the inheritance or gift agreement is higher than the one year average wage in North Macedonia in the previous year, according to Statistical Office. The value of all gifts from the same type, received within one year, represents one tax base. For the value of the gifts, the administration of the local authorities takes notes, upon which the receiver of gifts can be levied with tax at the end of the year. That will happen only if the person receives more gifts from same kind and in amount above the appointed sum.

The taxpayers of this law are physical or juridical persons residents of North Macedonia, which inherit real estate or receive real estate as a gift in the country or abroad and foreign physical and juridical person non-resident for the immovable and movable estate that is subject to inheritance or receives as gift on territory of North Macedonia.

If the inheritor leaves the inheritance to a person which would next come in line to own that inheritance and in case the inheritor does not do that, the tax is paid by the person that inherits the real estate. However, if the inheritor leaves the inheritance to certain person, which would not get the inheritance otherwise, then the inheritor that forwarded the inheritance is obliged to pay inheritance tax, and the person that receives the inheritance pays gift tax.

The tax rates for inheritance and gift are proportional and differ depending the inheritance order. The inheritor or receiver from first line is exempted from taxation. The inheritance tax and gift for second line is appointed at $2-3 \%$, and for inheritor from third line or someone who is not relative to the predecessor the tax is levied from $4-5 \%$. The rates of tax are determined by the Council of the local government.

The tax base for the inheritance tax and gift is the market value of the inherited real estate or real estate that is received as gift in the moment of imposition of tax liability and decreased for the debts and expenses for governance of the real estate which is subject to taxation.

Transfer tax on real estate is paid on the sale of one's real estate. Under transfer of real estate is considered transfer with or without fee of the ownership right on the real estate, as other means of acquiring real estate with or without fee between physical and juridical persons.

The taxpayer of the transfer tax of real estate is juridical or physical person - seller of the real estate. Under exclusion, obligator for transfer tax of real estate can be even the buyer of the real estate, if it is agreed in the agreement for sale of the real estate.

In the process of switching real estate taxpayer is the participator in the swop which in return gives real estate with higher value.

If the transfer is the ideal part of the ownership on real estate, then taxpayer is every owner separately. If the right to ownership of real estate is transferred under agreement for long life support, taxpayer is the receiver of real estate, i.e. his heirs.

The rates for transfer tax on real estate are proportional and start from 2 until $4 \%$. The rates are formed through decision in the Council of the community.

The tax base of the transfer tax on real estate is the market value of the real estate in the moment of creating the obligation. In case of switching real estate, the tax base is the 
difference in market values of the real estates that are switched. In case of transferring the ideal part of ownership on real estate, the tax base is the market value of the ideal part of the estate.

When the real estate is sold during bankruptcy proceedings, the tax base is achieved through sales price as result of competitive bidding or direct agreement, if the real estate is not sold through competitive bidding after two auctions.

\section{Proposals for Property Tax Reform in North Macedonia}

In the recent years, the large income inequality set up in motion serious gap in real estate ownership. Macedonian authorities does not care about the immense difference in property between the citizens, especially those who acquired substantial amount of real estate. This is obviously opposite of most countries in the EU. In North Macedonia the tax object is only the real estate and the tax rate is proportional and moves around 0.10 to $0,20 \%$ from the market value of the property, but if the person subject to taxation is living in the house or apartment then the tax rate is declined for $50 \%$. For example, in Slovenia the tax rates on property taxation are as follows: $0,15 \%$ for residential buildings, $0,75 \%$ for commercial and industrial real estate, $0,50 \%$ for empty apartments / buildings (vacation houses) and building land for residential and non-residential buildings with value over 500.000 euros the tax rate increases for $0,25 \%, 0,50 \%$ for unregistered residential real estates (for other illegal estate the tax rate multiplies by three).

The potential reform of the real estate taxes should be concentrated on taxation of large property in possession of one citizen. The changes should be as following: $0,05 \%$ for residential buildings (households), 0,20 \% for commercial and industrial real estate, 0,15\% for empty apartments / buildings (vacation houses) and building land for resident and nonresident buildings with value above 500.000 euros the tax rate should increase for $0,15 \%, 0,2$ $\%$ for unregistered residential real estates (for other illegal real estate the tax rate multiplies by three) [9].

On long term, the tax reform should aim towards implementation of wealth tax which would be based upon the total property of the citizens, immovable and movable estate (apartments, houses, cars, boats, even deposits in bank) where the tax obligator would be citizens who own total property over 1.000 .000 euros, and will subdue progressive tax rates (for example, tax rate of $1 \%$ for real estate value between 1 and 2 million euros, and tax rate of $1,5 \%$ for real estate value higher than 2 million euros).

However, in order to be able to implement taxation of that kind it is needed to have disposition and exact list of the real estate in possession of Macedonian citizens, which is missing currently. In that process of reform, it is needed to embed such list of estates. Also, the country requires broader collaboration with other countries on international level in order to be able to follow the money trails, which will occur I with the reform. That would inevitably trigger changes in behavior in this category of people. That would require additional tax modifications in order to reduce the income inequality such as:

- The real estate tax reform should be followed by increased excise duty $(30 \%)$ on automobiles with value over 40.000 euros;

- Second, to impose real estate and gift tax on receivers from first inheritance line, with exclusion of the spouse, if the value of the real estate is higher then 300.000 euros. The tax rate should be $1 \%$ from the value of real estate, and the assets would be transferred in local budget programs for building apartments for social categories of people with incentive to achieve equal opportunities for prosperity of next generations.

According to some tax experts, it is symptomatic that for the execution of taxes and duties on local level there is no adequate regulation. The local taxes are considered for "slow" taxes which are gathered mainly in the third and fourth quartal of the year. Anyway, it is obvious that there is serious problem with the regulation for local taxes that is required to be addressed. From the fiscal point of view, the local government thus not possess large jurisdiction and 
space for taking some measures, because of the dominant fiscal centralization. There are also problems with absence of supervision, i.e. there is no central body for surveillance in the communities, so the mayors are obliged to delegate special entitlements to some representatives from the local administration. Another crucial weakness is the weak efficiency of the local administration in tax collection, whereas the resources are not used on appropriate manner. Some of the areas that they stress out as possible space for improvement are several: the administrating of tax decree must be more efficient, improvements in the fiscal register, implementation of tax mailbox and some other measures.

According to some of them, there are serious problems in administration of property tax for which are necessary changes in legislative for tax procedure, property tax and money payments, but also to the methodology for assessment of property. That is the best way to reduce the negative reactions from the citizens and to improve the tax receipts which are not satisfactory. It is inevitable to make some changes in the assessment of the value of the property in order to have no reactions to the amount for taxation. The methodology for property assessment is very complex and most of the tax administration does not go out on field to directly asses the current situation with the real estate. The explanation from the local government is that they are in deficit with resources in order to achieve that and cover all properties. It is essential to simplify and secure the local government to realize the field check. That would be best done through the real estate register and massive assessment.

The people in the communities are mostly disappointed about the problems with judicial collection of tax decrees, which are followed by situations where the citizens are charged for already paid tax. They react also on high banking fees and for forceful execution of tax decrees. Especially the reactions on the legal condition to leave $2 / 3$ from their income is surprising factor, because some of them are struggling for existence. Beside those problems of the citizens, the local government is confronted with discoordination between institutions regarding issuance of tax decree to deceased people and situations where previous owners receive tax decree, because they did not inform the local administration for the changes in ownership of the property [10].

It is important to stress out that with the increased usage of modern technologies, lot of the communities went to secure online preview and payment of property tax. However, there are still people that are used to use the old way of communication with the local administration. Opposite of young families which are more inclined to use this method of tax services. Public campaign may produce better results in this area.

It is noted that local governments are aware for the possibilities of such proposals, but the problem with finances were always the biggest obstacle in achieving improvement and modernization of governance with taxes. Hopefully, the Ministry of Finance will be able to secure some funds from the Program for public finance management in amount of 40 million euros from European Union. That would be very beneficial for local governments through better governance in communities, real estate cadaster, updating the address register in order to improve the percentage of tax collection on long run.

\section{Conclusions}

With the ongoing process of fiscal decentralization, the property tax comes more to light as one of fundamental public revenues for the municipalities necessary for providing qualitative public goods and services. Within the last ten years there have been a lot of remarks about the increased inequality between the rich and poor people. One of the attempts to reduce the problem was to implement progressive income tax. However, the start of the implementation did not fulfill the government expectations and was prolonged for 2021. The same idea applies for the property tax. A lot of experts try to impose progressive property tax as a mean to reduce the inequality and to impose social justice. Meanwhile the real situation is very different in the local governments. We have a lot of municipalities that have serious issues with the personal equipment. Another more important thematic is the tax collection, which is unsatisfactory. There are a lot of factors that affect that situation, such as: uneducated citizens about the 
property tax and its purpose, registration of real estate, updates of the info's for addresses, the absence of marketing on e-tax services, inefficient administration, problems with forceful charge of property tax, etc. So, the previous suggestion for progressive property tax maybe should be postponed for some future time and focus on improvements of the current tax payment and revise some of the many tax reliefs and exemptions. If the municipalities decide to increase the tax rate under unchanged market value of the real estate, that would create serious additional problems and higher tax evasion. Probably the best approach for now would be to increase the efficiency of tax administration and remove the previously mentioned factors responsible for poor tax collection.

\section{References}

1 PKF, Czech Republic Tax Guide 2013, May;

2 Radvan, M. Czech Tax Law, Masaryk University, Faculty of Law Publications, 2010, No. 454;

3 Gacov, P. Gockov, G. Petrevski, G. Popovski, N. Tevdovski, D. Uzunov, V. Filipovski, V. Reformi za pravedno odanocuvanje, Strucna monografija, Skopje, 2016, p. 32;

4 https://www.gov.uk/inheritance-tax;

5 Kon popraveden i poefikasen system na danoci na imot: Analiza na danocnoto administriranje na grad Skopje, Asocijacija za razvojni inicijativi - Zenit Skopje, 2018, p. 35;

6 Godar, S. Truger, A. Shifting priorities in EU tax policies, 2017, May;

7 https://finance.gov.mk/mk/node/898;

8 Property Tax Law, Official Gazette, No. 61/2004;

9 Gacov, P. Gockov, G. Petrevski, G. Popovski, N. Tevdovski, D. Uzunov, V. Filipovski, V. Reformi za pravedno odanocuvanje, Strucna monografija, Skopje, 2016, p. 64;

10 Kon popraveden i poefikasen system na danoci na imot: Analiza na danocnoto administriranje na grad Skopje, Asocijacija za razvojni inicijativi - Zenit Skopje, 2018; 